\title{
LAGU SETIA JANJIKU: BENTUK PEMBARUAN MUSIK KERONCONG GAYA ISMANTO
}

\author{
Soladi $^{1}$, Wisnu Mintargo ${ }^{2}$, dan Kiswanto ${ }^{3}$ \\ ${ }^{1}$ Prodi Etnomusikologi Fakultas Seni Pertunjukan Institut Seni Indonesia Surakarta \\ ${ }^{2}$ Prodi Etnomusikologi Fakultas Seni Pertunjukan Institut Seni Indonesia Surakarta \\ ${ }^{3}$ Prodi Etnomusikologi Fakultas Seni Pertunjukan Institut Seni Indonesia Surakarta \\ E-mail:wsoladi@gmail.com|0812-7343-6848
}

\begin{abstract}
Songs that develop in keroncong music have been classified strictly based on their form, including the keroncong asli, langgam, stambul, and several other forms. The classification has become a very chain rule, as a result the creativity that emerges among keroncong musicians is often considered to be incompatible with the standards or parameters aesthetic of keroncong music by most keroncong music performers. These conditions do not always limit the composers and / or creators of keroncong songs to be creative in producing new products with different styles. One of them can be found in Ismanto's artworks around the 1960s. In one of his songs entitled Keroncong Setia Janjiku, Ismanto seems to have hit the boundaries that have been applied, but has a novelty with a strong character. The findings of this study indicate that the Song Setia Janjiku is a song keroncong asli that nglanggami.
\end{abstract}

Keywords: Keroncong, Ismanto, New Style, Keroncong Asli, Langgam Jawa, Nglanggami

\begin{abstract}
ABSTRAK
Lagu-lagu yang berkembang dalam musik keroncong telah diklasifikasikan secara ketat berdasarkan bentuknya, di antaranya keroncong asli, langgam, stambul, dan beberapa bentuk lainnya. Pengklasifikasian tersebut telah menjadi aturan yang sangat mengikat, akibatnya kreativitas-kreativitas yang muncul diantara para musisi keroncong seringkali dianggap kurang sesuai dengan standar atau parameter estetika musik keroncong oleh kebanyakan pelaku musik keroncong. Kondisi tersebut tidak selalu membatasi para komponis dan/atau pencipta lagu keroncong untuk berkreativitas menghasilkan produk-produk baru dengan gaya yang berbeda. Salah satunya dapat ditemukan pada karya-karya Ismanto pada sekitar tahun 1960an. Pada salah satu lagunya yang berjudul Keroncong Setia Janjiku, Ismanto tampak menabrak batasbatas yang telah berlaku, tetapi memiliki kebaruan dengan karakter yang kuat. Temuan dari penelitianini menunjukkan bahwa Lagu Setia Janjiku merupakan lagu keroncong asli yang nglanggami.
\end{abstract}

Kata kunci: Keroncong, Ismanto, Gaya Baru, Keroncong Asli, Langgam Jawa, Nglanggami. 


\section{PENDAHULUAN}

Keroncong sebagai musik pop tertua di Indonesia yang berawal dari pengaruh kedatangan bangsa Portugis pada abad ke-15 telah berkembang dengan beragam bentuk yang secara umum terbagi menjadi keroncong asli, stambul, langgam, dan irama Melayu (Suadi, 2017: 10). Di dalam tradisi komunitas musik keroncong, istilah keroncong juga memiliki banyak pengertian: antara lain sebagai sebutan untuk instrumen musik yang bernama $c u k$ (ukulele dengan 3 dawai), sebagai sebutan genre atau jenis musik, sebagai kesatuan atau kelompok keroncong, dan/atau sebagai bentuk lagu (Nardi, n.d.: 12). Menurut Harmunah (1987: 21-22), perkembangan musik keroncong di Indonesia telah mencapai puncak kepopulerannya pada abad ke19 yang dikenal dengan era keroncong abadi ${ }^{1}$. Sejak saat itu, keroncong telah dikenal sebagai musik Indonesia setelah mengalami berbagai perubahannya, meliputi instrumen dan gaya permainan khas yang kemudian disebut keroncong asli. Instrumen yang digunakan pada sajian keroncong asli adalah biola, flute, bass, cello (selo), cak (banyo), cuk (ukulele), dan gitar. Beberapa jenis atau bentuk lagu yang erat dengan irama musik keroncong antara lain adalah lagu keroncong asli, langgam, dan stambul, namun hampir semua lagu seperti dangdut, campur cari, dan/atau lagu-lagu populer lainnya sebenarnya dapat diiringi dengan irama keroncong.

Salah satu bentuk perubahan atau pembaruan yang terjadi sekitar tahun 1960-an adalah karya-karya dari komponis dan penyanyi keroncong bernama Ismanto. Fenomena pembaruan dan pengembangan bentuk atau gaya lagu keroncong terlihat jelas pada beberapa karyanya yang memiliki karakteristik berbeda dengan bentuk lagu keroncong pada umumnya. Pembaruan tersebut dilakukan tanpa menghilangkan citranya sebagai lagu keroncong. Hal itu dapat diamati pada tiga karyanya, yaitu Kr.Tuladha, Kr. Jangan Bimbang dan Kr. Setia Janjiku. Ketiga lagu tersebut memiliki karakteristik khusus dan khas apabila dibandingkan dengan lagu keroncong pada umumnya.
Karakteristik tersebut dibangun dengan penggarapan unsur-unsur melodi, harmoni, dan gaya musikal, misalnya pada lagu Kr. Setia Janjiku yang tampak memadukan unsur-unsur langgam Jawa pada sebagian sajiannya meskipun termasuk dalam kategori keroncong asli.

Fokus penelitian ini adalah membahas lagu Setia Janjiku sebagai bentuk pembaruan (inovasi) gaya lagu keroncong yang dihasilkan oleh Ismanto. Kebaruan bentuk lagu (di dalamnya termasuk gaya musikal) dalam musik keroncong merupakan hasil dari upaya kreatif yang dilakukan oleh pencipta lagu dan/atau komponis melalui penggabungan unsurunsur dari berbagai macam bentuk lagu (di dalamnya termasuk gaya musikal) keroncong yang sudah ada sebelumnya, misalnya seperti keroncong asli, langgam Jawa, stambul, dan lain-lain. Hal itu dapat diamati pada bentuk dan struktur lagu Setia Janjiku yang di dalamnya bermuatan keroncong asli dan langgam Jawa. Percampuran antara kedua gaya tersebut memunculkan kesan atau cita rasa tersendiri dengan karakteristik atau ciri khas yang berbeda.

Konsep mengenai gaya (style) dapat dipahami sebagaimana yang dijelaskan oleh (Nettl, 2012: 165), yaitu “...agregasi karakteristikkarakteristik yang dimiliki oleh suatu komposisi, dan yang juga dimiliki oleh komposisi-komposisi lain dalam kompleks budaya yang bersangkutan." Hal itu serupa dengan penjelasan Gell (1998: 155-159) yang memaknai gaya sebagai sebuah konfigurasi atribut darisuatu pola atau cara yang citranya dikenali sebagai bentuk identitas (lihat Kiswanto dkk., 2019: 74). Kebaruan gaya dalam lagu Setia Janjiku dapat dianalisis lebih jauh dengan mengidentifikasi perbedaan unsur-unsur musikalnya terhadap konvensi atau format langgam dan keroncong asli, serta menunjukan kesamaan-kesamaan yang menunjukkan identitasnya sebagai lagu keroncong.

Berdasarkan studimengenai kebaruan gaya pada lagu Setia Janjiku, maka dapat ditemukan nilainilai atau kaidah-kaidah penciptaan lagu keroncong kaitanya dalam menghasilkan kebaruan. Setiap karya baru yang diciptakan oleh seorang seniman tidak serta merta lahir begitu saja, melainkan diperoleh melalui pengkombinasian- 
pengkombinasian atau pencampuran-pencampuran antara beberapa unsur yang telah ada sebelumnya. Relasi antara kebaruan dan pencampuran menjadi penting untuk ditekankan sebagai prinsip-prinsip dasar yang dapat diterapkan dalam menciptakan lagu keroncong dengan gaya atau versi baru oleh seniman yang lebih luas. Relasi yang demikian dapat dilihat dan dicermati pada bentuk karya yang dihasilkan. Damono (2014: 16) menyebut fenomena semacam itu sebagai proses intertekstual pada sebuah teks: yang menjadi baru karena merupakan himpunan teks-teks lain (lagu lainnya) yang ada sebelumnya.

\section{TINJAUAN PUSTAKA}

Penelitian mengenai musik keroncong telah banyak dihasilkan oleh para peneliti sebelumnya, namun tidak ada satupun yang secara khusus membahas mengenai kesenimanan dan karya-karya Ismanto. Sejauh ini hanya Budiman (1979) yang telah mengulas tentang profil Ismanto, yakni di dalam bukunya yang lebih banyak membahas tentang teknik permainan musik keroncong, sejarah, beserta profil dari tokoh-tokoh musik keroncong.

Sejarah, gaya, dan perkembangan musik keroncong di Indonesia telah banyak dijelaskan oleh Harmunah (1987), termasuk juga Ganap (2011) yang secara lebih spesifik membahas mengenai Keroncong Toegoe sebagai musik hybrid yang dihasilkan dari membaurnya budaya Portugis dan budaya Indonesia. Di samping itu ada juga Suadi (2017) yang lebih banyak membahas tentang sejarah musik populer di Indonesia, di dalamnya juga disebutkan bahwa keroncong sebagai musik populer pertama di Indonesia. Penelitian lain mengenai musik keroncong seperti yang dihasilkan Sodik (2002), Sugiyanto (2003), Darini (2012), Rachman(2013), Akbar (2013), Wardani(2014), Nugroho (2015), Ratna Sari (2015), Widyanta (2017), dan Fikri (2017) juga semakin memperkaya pengetahun mengenai musik keroncong dengan keberagaman topik, perspektif, dan obyek yang dibahas.

\section{METODE}

Penelitian inimenggunakan metode kualitatif yang bersifat deskriptif dan analitik untuk menganalisis dan menjelaskan permasalahan yang diajukan. Tahap-tahap yang dilakukan dalam penelitian di antaranya adalah mengumpulkan datadata yang relevan sebanyak mungkin melalui proses pengamatan, pengamatan terlibat, dan dokumentasi terhadap berbagai aktivitas musikal dan non-musikal para musisi dan komunitas keroncong di Surakarta, wawancara dengan beberapa narasumber yang cukup mengenal Ismanto, studi kepustakaan yang terkait dengan topik permasalahan dan pembahasan, serta studi arsip dokumen dan rekaman musik yang terkait dengan Ismanto.

Data-data yang telah dikumpulkan kemudian diolah agar dapat dideskripsikan di atas kertas, antara lain dengan mentranskripsi notasi musik, menyalin hasil wawancara, serta memilih gambar dan foto yang cukup representatif untuk digunakan menjelaskan.

Data-data yang telah dikumpulkan dan diolah, selanjutnya dianalisis dan dideskripsikan secara interpretatif melalui pendekatan diakronik (kronologi sejarah) yang mengkaitkan dan mengorganisasikan teori dan fakta ke dalam penafsiran-penafsiran antara bentuk teks lagu dan gaya musik yang dihasilkan Ismanto dengan bentukbentuk teks lagu dan gaya musik yang telah ada dan berkembang sebelumnya. Cara berpikir kronologis yang terkait dengan sejarah dapat membantu merekonstruksi kembali peristiwa atau kejadian yang pernah terjadi di masa lampau (Galtung, 1970: 94). Hal itu didasari atas ketiadaan Ismanto yang telah meninggal dunia sejak tahun 1996, sedangkan lagu Setia Janjiku diperkirakan diciptakan sekitar tahun 1960-an.

\section{PEMBAHASAN}

\subsection{Biografi Kesenimanan Ismanto}

Ismanto merupakan seorang tokoh yang berpengaruh dalam perkembangan musik keroncong di Indonesia. Ia lahir diAmbarawa pada 
tahun 1920 dan wafat di Surakarta pada 1996. Peranannya di dalam musik keroncong adalah sebagai komponis lagu dan penyanyi. Ismanto tinggal di Surakarta tepatnya di kelurahan Nusukan. Sebelum namanya besar dalam dunia musik keroncong, Ismanto bekerja sebagai karyawan di sebuah toko sepatu bernama toko "Sadinoe".

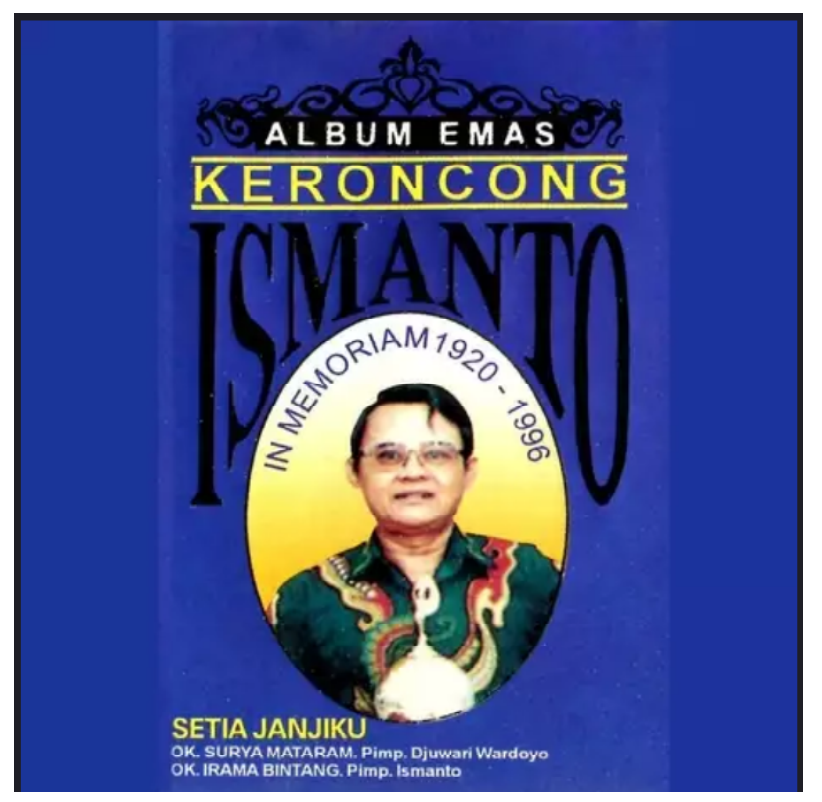

Gambar 1. Ismanto dalam profil kaset Album Emas Keroncong

(audiolibrary.rri.co.id/v2/album/409/ismanto/albumemas-keroncong-ismanto)

Mulanya Ismanto munculdi Radio Republik Indonesia (RRI) Surakarta bersama dengan orkes keroncong (O.K) Sederhana pimpinan Aliman pada tahun 1950. Selain itu Ismanto juga bergabung dengan OK. Bunga Mawar asuhan Suprono. Karena suara Ismanto yang menarik, pihak RRI mengajak bergabung dengan Radio Orkes Surakarta (ROS) Pimpinan Kamsidi pada tahun 1951. Sejak saat itu Ia mulai dinas di RRI sebagai karyawan musik. Kemampuan Ismanto dalam bernyanyi keroncong memang tidak bisa diragukan lagi, terbukti dengan prestasi yang diraihnya sebagai juara bintang radio tingkat nasional tiga kali berturut-turut pada tahun 1956, 1957, dan 1958. Kemudian pada tahun 1959 Ismanto di tugaskan untuk mengikuti misi kesenian ke Malaysia bersama Orkes Studio
Djogjakarta(OSD) pimpinan Saiful Bahri. Pada tahun 1961 Ismanto ke Rusia, Cina, Korea, Vietnam, dan India selama tiga bulan bersama rekannya Bagong Kusudiharjo untuk menjalani misi kebudayaan yang dipimpin oleh Sumaryo (Budiman, 1979:170-171).

Setelah menyelesaikan misi kebudayaan, Ismanto melanjutkan karirnya sebagai karyawan musik di RRI dan menjalani beberapa produksi rekaman lagu keroncong. Ismanto merupakan penyanyi dan pencipta lagu yang produktif. Sebagai pencipta lagu, Ismanto juga menyanyikan lagu-lagu dari karya seniman lainnya dalam albumnya. Hal ini yang menjadikan Ismanto memiliki banyak teman untuk berbagi ilmu dalam hal menciptakan lagu keroncong. Salah satu temannya yang paling erat adalah pencipta lagu asal Semanggi, Pasarkliwon, Surakarta yang bernama Waluya. Ismanto begitu mengidolakan karya-karya dari Waluya dan mereka juga beberapa kali bekerja sama dalam musik keroncong (Hartono, wawancara 27 Mei 2019).

Ismanto melakukan kerjasama dengan beberapa studio rekaman di Surakarta, Semarang, dan Jakarta. Studio rekaman menawarkan produksi rekaman untuk lagu-lagu ciptaan Ismanto. Suatu ketika Ismanto sedang proses rekaman di salah satu studio di Semarang selama dua hari untuk produksi satu album. Kemudian dari pihak produser meminta Ismanto untuk menambah lagu untuk satu album lagi dan diminta tinggal dulu di Semarang. Ismanto mulanya menolak karena permintaan terlalu mendadak dan belum menyiapkan satu pun lagu baru, namun akhirnya Ismanto memutuskan membuat beberapa lagu baru. Beriringan dengan proses rekaman yang sedang berlangsung, Ismanto memanfaatkan sela-sela waktu untuk menciptakan lagu yang diminta untuk produksi album rekaman selanjutnya. Seperti itu diungkapkan oleh Hartono, rekan Ismanto yang saat itu sebagai pemain gitar dalam Radio Orkes Surakarta (ROS) (Hartono, wawancara 27 Mei 2019).

Ismanto dianggap sebagai penyanyi yang berkualitas dengan cengkok yang khas. Selain sebagai penyanyi, peran Ismanto sebagai pencipta lagu juga memiliki pengaruh serta kesan tersendiri 
pada masyarakat seniman keroncong. Ismanto merupakan pencipta lagu keroncong yang produktif dan kreatif. Produktivitas Ismanto bisa dilihat dari berapa banyak karya-karya yang dihasilkannya. Informasi yang sering penulis dengar dari senimanseniman keroncong di Surakarta, Ismanto memiliki hingga lebih dari 300 karya lagu. Hal itu diperjelas oleh tulisan dalam surat kabar (redaksi tidak diketahui) yang terbit pada tahun 1984 berikut ini.

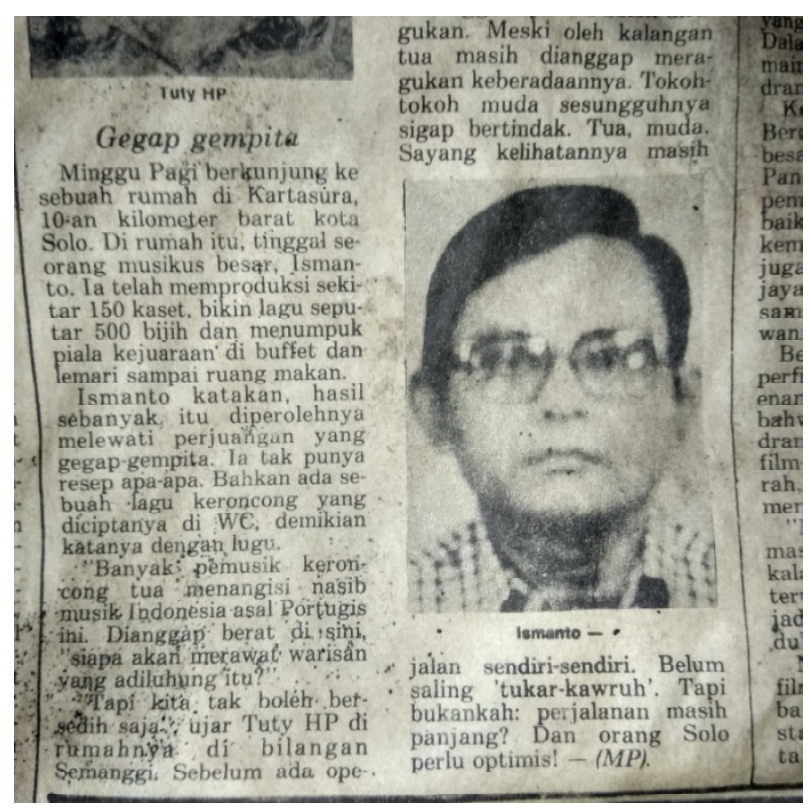

Gambar 2. Essay tentang Ismanto dalam surat kabar Minggu Pagi No. 381 Januari 1984 (Sumber: Koleksi Hartono, diakses 26 Juni 2019)

Pada 30 Desember 2016, HAMKRI cabang Surakarta menggelar acara "Tribute to Ismanto". Acara digelar pada pukul 19.30 WIB selasai bertempat di Joglo Sriwedari dengan pengisi acara Orkes keroncong KLJ (Keroncong Lesehan Joglo). Selain itu acara juga dimeriahkan dengan mengundang teman-teman penyanyi Ismanto untuk menyanyi lagu-lagu karya Ismanto. Acara yang digelar menandakan seberapa penting dan besar kontribusi Ismanto untuk musik keroncong. Sampai saat ini lagu-lagu ciptaan Ismanto masih sering dinyanyikan bahkan juga sebagai materi dalam beberapa acara kompetisi menyanyi atau group musik keroncong.

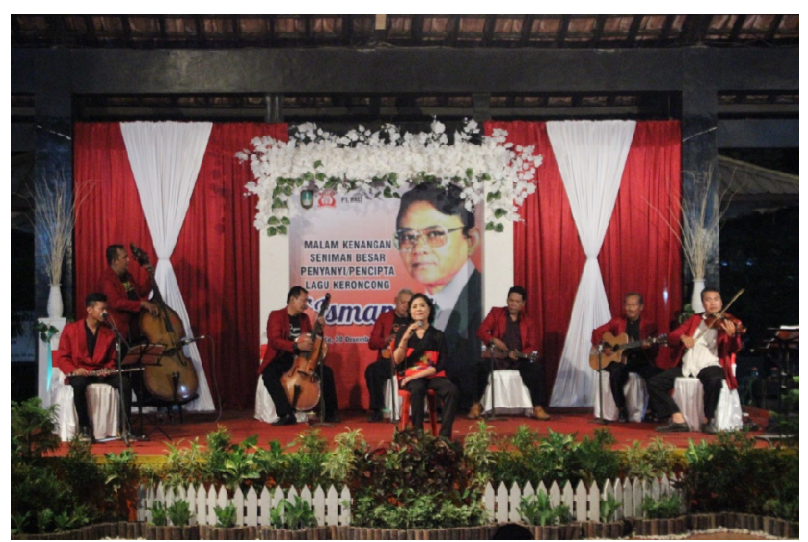

Gambar 3. Orkes Keroncong KLJ dalam acara Tribute to Ismanto (Foto : Soladi, 2016)

Seseorang yang dianggap sebagai tokoh, tentu memiliki peran yang besar dalam suatu tempat, bidang keilmuan, atau membangun sebuah kesan istimewa yang diakui kelompok masyarakat tertentu. Hal demikian yang akhirnya memunculkan alasanalasan mengapa seseorang tersebut ditokohkan. Seorang Ismanto dalam pandangan beberapa seniman keroncong di Surakarta, merupakan tokoh yang istimewa dan mengesankan, khususnya dalam menyanyi dan mencipta lagu keroncong.

Kus Sudiarso sebagai penyanyi keroncong mengungkapkan bahwa cara bernyanyi Ismanto itu cengkoknya kemayu, ambitus suaranya tinggi (tenor), dan mampu menyampaikan maksud dari lagu yang dinyanyikan. Kus Sudiarso juga mengungkap bahwa biasanya seorang penyanyi keroncong yang bagus menyanyi keroncong asli, banyak kemungkinan ketika menyanyi langgam Jawa menjadi kurang bagus karena tekniknya juga berbeda. Begitu pun sebaliknya, orang yang bagus menyanyikan langgam Jawa biasanya kurang jika menyanyikan keroncong asli. Namun Ismanto mampu membawakan lagu keroncong asli maupun langgam Jawa dengan kualitas yang sama-sama bagus (Kus Sudiarso, wawancara 18 Maret 2019).

Kemampuan Ismanto dalam bernyanyi mendukung atas kualitas lagu yang diciptakannya. Dengan menyanyi, Ismanto mendapat pengalaman musikal yang luas lewat lagu-lagu yang dinyanyikan. Pengetahuan berupa melodi, lirik, tema lagu, 
penataan sastra membuat Ismanto mampu menghasilkan inovasi-inovasi sebagai produk kreativitasnya. Danis Sugiyanto menyebut Ismanto merupakan pioner penciptaan lagu-lagu keroncong asli yang berbeda (Danis Sugiyanto, wawancara 2019).

Di antara karya-karya Ismanto yang begitu banyak, pembaruan yang dilakukan Ismanto dapat dilihat pada salah satu lagunya yang berjudul Setia Janjiku. Lagu tersebut termasuk jenis keroncong asli, namun juga memiliki karakteristik langgam Jawa. Artinya, lagu tersebut tampak mengadopsi dua gaya yang berbeda untuk dipadukan menjadi sebuah satu kesatuan (unity) dengan karakteristiknya sendiri. Paparan pada bab ini menunjukan posisi Ismanto sebagai pencipta lagu, penyanyi, serta tokoh keroncong yang berpengaruh di Surakarta.

\subsection{Modus Mayor dan Pelog Keroncong}

Sajian lagu Keroncong Setia Janjiku dalam sebuah rekaman yang diproduksi oleh Pusaka Record pada 1984 memunculkan fenomena lagu keroncong asli yang bernuansa Jawa. Lagu ini tampak mengadopsi dua gaya yang berbeda untuk dipadukan menjadi sebuah satu kesatuan (unity) yang membentuk karakteristiknya sendiri. Struktur lagu ini identik dengan lagu keroncong asli, namun terdapat bagian-bagian yang bermuatan unsur-unsur langgam Jawa.

Apabila dicermati lebih dalam, lagu ini tampak menggunakan dua modus nada di dalamnya, yaitu diatonis (mayor) dan pentatonis yang mengarah atau menyerupai laras pelog pada karawitan Jawa. Maksud dari menyerupai laras pelog adalah penggunaan atau pemilihan nada yang intervalnya mendekati sistem pelarasan pelog pada gamelan Jawa. Praktisi musik keroncong mengenal tangga nada pentatonis ini sebagai pelog keroncong, karena sebenarnya tidak sama persis dengan laras pelog pada gamelan Jawa. Perbandingan antara susunan tangga nada diatonis (mayor), pelog keroncong, dan pelog gamelan dapat dilhat pada not di bawah ini.
Tabel 1. Perbandingan tangga nada/laras antara Diatonis, Pelog Keroncong/Pentatonis, dan Pelog Gamelan/Karawitan

\begin{tabular}{|l|c|c|c|c|c|c|c|}
\hline Diatonis & $\begin{array}{c}1 \\
(\mathrm{do})\end{array}$ & $\begin{array}{c}2 \\
(\mathrm{re})\end{array}$ & $\begin{array}{c}3 \\
(\mathrm{mi})\end{array}$ & $\begin{array}{c}4 \\
(\mathrm{fa})\end{array}$ & $\begin{array}{c}5 \\
(\mathrm{sol})\end{array}$ & $\begin{array}{c}6 \\
(\mathrm{la})\end{array}$ & $\begin{array}{c}7 \\
(\mathrm{si})\end{array}$ \\
\hline $\begin{array}{l}\text { Pelog Keroncong } \\
\text { (pentatonis) }\end{array}$ & $\begin{array}{c}1 \\
(\mathrm{do})\end{array}$ & - & $\begin{array}{c}3 \\
(\mathrm{mi})\end{array}$ & $\begin{array}{c}4 \\
(\mathrm{fa})\end{array}$ & $\begin{array}{c}5 \\
(\mathrm{sol})\end{array}$ & - & $\begin{array}{c}7 \\
(\mathrm{si})\end{array}$ \\
\hline $\begin{array}{l}\text { Pelog gamelan/ } \\
\text { karawitan(kepatihan) }\end{array}$ & $6(\mathrm{nem})$ & $7(\mathrm{pi})$ & $1(\mathrm{ji})$ & $2(\mathrm{ro})$ & $3(\mathrm{lu})$ & $4(\mathrm{pat})$ & $5(\mathrm{mo})$ \\
\hline
\end{tabular}

Permainan nada-nada dengan modus pentatonis (pelog keroncong) sering digunakan secara konsisten untuk kategori bentuk lagu langgam Jawa, sedangkan permainan nada-nada dengan modus mayor dan minor sering digunakan secara konsisten untuk kategori bentuk lagu keroncong asli. Pembagian nada-nada dan melodi yang dimainkan secara berurutan melalui kedua modus tersebut dapat diamati pada notasi di bawah ini.

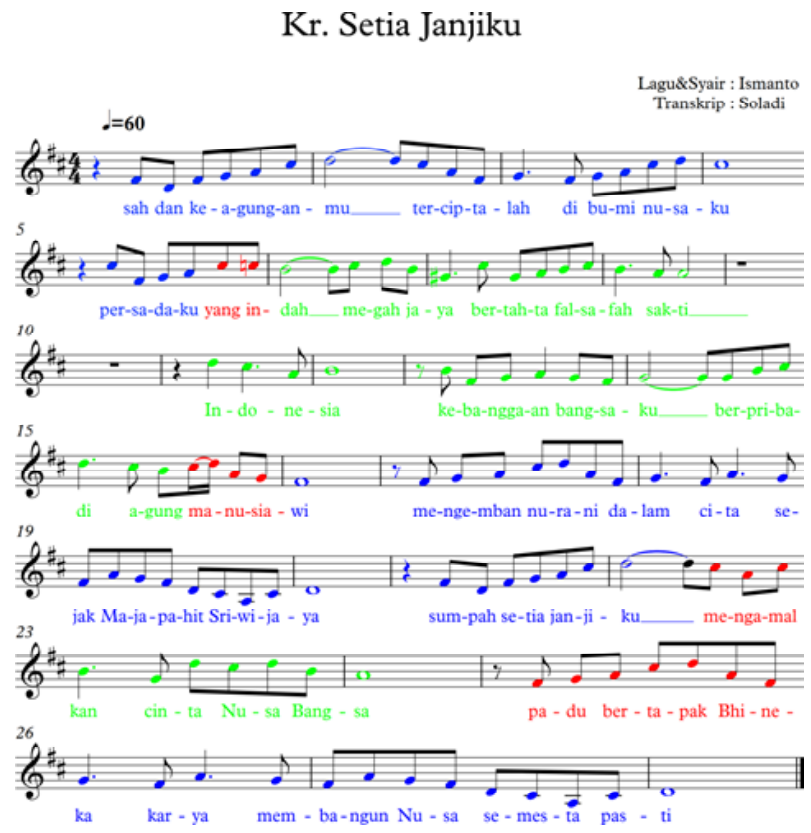

Notasi 1. Notasi lagu Kr. Setia Janjiku (Transkriptor: Soladi)

Transkrip lagu dengan notasi di atas digambarkan dengan warna-warna yang berbeda. Notasi yang berwarna biru untuk menandai melodi lagu dengan modus tangga nada pentatonis (pelog keroncong), sedangkan notasi yang berwarna hijau untuk menandai melodi lagu dengan modus tangga nada diatonis (mayor). Sementara itu, notasi yang berwarna merah sebagai tanda motif melodi yang 
berperan sebagai penghubung antara modus tangga nada mayor dan pelog keroncong.

\subsection{Keroncong Asli dan Langgam Jawa}

Irama langgam Jawa dalam musik keroncong sebenarnya bukan sesuatu yang asing atau tidak biasa, namun terdapatnya irama langgam Jawa pada lagu keroncong asli merupakan hal yang tidak wajar. Lagu keroncong asli umumnya sudah mempunyai pakem dan iramanya sendiri. Lagu keroncong asli berstruktur $\mathrm{A}-\mathrm{B}-\mathrm{C}$, dimulai dengan awalan solo biola atau flute atau gitar dengan mengambil potongan melodi musik klasik mirip dengan kadensa yang dalam keroncong disebut prospel. Kemudian disusul dengan instrumen lainnya danflute atau biola memainkan melodi pengantar lagu, biasanya melodi yang di pakai adalah 4 birama dari bagian $\mathrm{C}$. Selanjutnya masuk bagian A terdiri dari 8 birama, kemudian interlude 2 birama, disusul bagian $\mathrm{B}$ yang terdiri dari 10 birama, dan bagian $\mathrm{C}$ yang terdiri dari 8 birama bagian koda berupa progresi kord I - IV $-\mathrm{V}-\mathrm{I} / 1-4-5-1$. Jadi lagu keroncong asli memiliki 28 birama bila dihitung mulai dari masuknya lagu/vokal. Contoh lagu keroncong asli adalah Senggenggam Harapan Cipt. Budiman BJ, Jiwa Merana Cipt.Ismanto, dan Bumi Emas Cipt. Gesang.

\section{Lagu Keroncong Asli}

Irama Keroncong

|| prospel \|

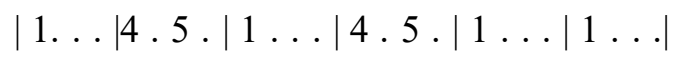

Violin/Flute/Gitar semua instrumen

A. $\quad|1 \ldots| 1 \ldots|5 \ldots| 5 \ldots|2 \ldots| 2 \ldots \mid$

$|5 \ldots| 5 \ldots|5 \ldots| 5 \ldots \mid$

interlude

B. $\quad|4 \ldots| 4 \ldots|4 \ldots| 4.5 . \mid$

$|1 \ldots| 1 \ldots|5 \ldots| 5 \ldots \mid$

C. $\quad|1 \ldots| 4.5 .|1 \ldots| 4.5 . \mid$

$|1 \ldots| 1 \ldots|5 \ldots| 5 \ldots \mid$

Coda. $|1 \ldots| 4.5 .|1 \ldots|$

Notasi 2. Struktur serta progresi akord pada lagu

Keroncong asli
Langgam Jawa dalam musik keroncong merupakan bentuk lagu yang disajikan dengan pola permain menyerupai gamelan pada karawitan, namun disajikan dengan alat musik keroncong. Pada umumnya lagu ini memiliki 2 bagian yaitu $A$ dan $B$ dengan urutan sajian $\mathrm{A}^{\mathrm{I}}-\mathrm{A}^{\mathrm{II}}-\mathrm{B}-\mathrm{A}^{\mathrm{II}}$. Lagu langgam Jawa umumnya memiliki 32 birama. Untuk mengawali sajian langgam Jawa biasanya menggunakan bawa, atau sebagai alternatifyang lain menggunakan intro yang diambil dari 8 birama bagian akhir lagu tersebut. Setelah intro masuk bagian $\mathrm{A}^{\mathrm{I}}$ sepanjang 8 birama, kemudian lanjut ke $\mathrm{A}^{\mathrm{II}}$ dengan 8 birama, kemudian masuk bagian $\mathrm{B}$ sepanjang 8 birama, lanjut lagi ke $\mathrm{A}^{\mathrm{II}}$ sepanjang delapan birama, kemudian ke interlude atau bisa langsung ke koda.

Bentuk lagu langgam Jawa terdapat pembagian jenis irama layaknya irama pada gamelan, namun lebih bebas dan setiap individu atau kelompok mempunyai tafsir yang berbeda-beda. Karakteristik musikal Jawa dibangun dengan unsurunsur yang diadopsi dari beberapa konsep-konsep pada karawitan. Selain itu secara suara yang dihasilkan dan melodi yang disusun juga diupayakan untuk mendekati laras-laras yang ada pada gamelan. Jadi untuk lagu langgam Jawa bisa dikatakan memiliki kebebasan dalam perpindahan selehnya, namun tetap menggunakan nada-dana yang sesuai dengan laras yang dipakai. Karena memang merupakan sebuah hasil dari adaptasi lagu pop atau langgam keroncong terhadap budaya musikal Jawa. Contoh lagu langgam Jawa yaitu Yen ing Tawang ana Lintang (Andjar Any), Kenya Sulistya (Kaswadi), Kembang Melati Mekar Sore (Ismanto), Caping Gunung (Gesang). Nyungging Ati (Ismanto), Wuyung (Ismanto). Sebagai contoh, berikut adalah struktur sajian langgam Jawa Yen ing Tawang ana Lintang : 


\section{Lgm.Jw. Yen ing Tawang ana Lintang}

Bawa atau Intro

$$
\begin{array}{r}
\mathrm{A}^{\mathrm{I}}|5 \ldots| 4 \ldots|3 \ldots| 3 \ldots \mid \\
|7 \ldots| 4 \ldots|3 \ldots| 3 \ldots \mid \\
\mathrm{A}^{\mathrm{II}}|5 \ldots| 4 \ldots|3 \ldots| 3 \ldots \mid \\
|7 \ldots| 4 \ldots|1 \ldots| 1 \ldots \mid \\
\mathrm{B}|4 \ldots| 4 \ldots|3 \ldots| 3 \ldots \mid \\
|7 \ldots| 1 \ldots|3 \ldots| 3 \ldots \mid \\
\mathrm{A}^{\mathrm{II}}|5 \ldots| 4 \ldots|3 \ldots| 3 \ldots \mid \\
|7 \ldots| 4 \ldots|1 \ldots| 1 \ldots \mid \\
\text { suwuk }
\end{array}
$$

Coda. $|1 \ldots| 4.5 .|1 \ldots| \mid$

Notasi 3. Struktur serta progresi seleh pada lagu langgam Jawa

Penulisan notasi di atas memang terdapat beberapa bagian atau ornamen musik yang disebut dengan mengambil istilah dari karawitan dan musik barat. Sehingga ada istilah suwuk, bawa, seleh yang dipinjam darikarawitan serta ada istilah intro, birama, koda yang diambil dari musik barat. Meskipun dalam sajiannya menggunakan sistem seleh seperti halnya gamelan, penulisan simbol selehnya tidak menggunakan Ji, ro, lu, mo, nem dalam notasi kepatihan melainkan tetap menggunakan solmisasi not angka. Karena tidak cocok bila kepatihan digunakan pada langgam Jawa dalam musik keroncong, kecuali lagu langgam Jawa yang disajikan dengan iringan gamelan.

\subsection{Garap Gaya Baru dari Keroncong Asli dan Langgam Jawa}

Lagu Setia Janjiku umumnya disebut sebagai lagu keroncong asli, namun jika mengamati unsurunsur musikal yang membentuknya tidak sepenuhnya demikian karena ada beberapa bagian-bagian yang unsur-unsurnya keluar dari pakem keroncong asli. Lagu Setia Janjiku dapat disebut sebagai lagu keroncong asli yang nglanggami, karena adanya unsur-unsur langgam Jawa yang dipadukan di dalamnya, baik secara sinkronis (hubungan struktural) mapun diakronis (urutan sajian).

Perpaduan antara keroncong asli dan langgam Jawa pada lagu Setia Janjiku dapat dilihat pada skema sajian berikut ini.

Tabel 2. Skema sajian lagu Setia Janjiku (Hasil transkripsi rekaman lagu Setia Janjiku Mp3 Album Emas Keroncong)

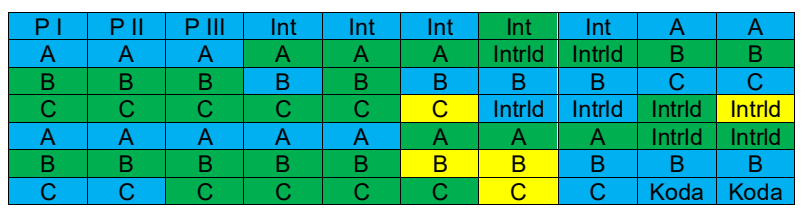

Keterangan :

\begin{tabular}{|l|l|}
\hline & Dalam Irama Keroncong/Gaya permainan Keroncong \\
\hline & Dalam Irama Langgam Jawa/Gaya permainan Langgam Jawa \\
\hline & masing-masing Instrumen berbeda gaya(Campuran) \\
\hline P I & Prospel pertama \\
\hline P II & Prospel kedua \\
\hline P III & Prospel kedua \\
\hline A & Lagu bagian pertama \\
\hline B & Lagu bagian kedua \\
\hline C & Lagu bagian ketiga \\
\hline Int & Intro lagu/musik pengantar lagu \\
\hline Intrld & Interlude/musik pada tengah lagu \\
\hline Koda & Musik penutup sajian musik/lagu \\
\hline
\end{tabular}

Sajian lagu Setia janjiku dimulai dengan awalan solo biola atau prospel, kemudian disusul dengan instrumen lainnya dalam akord 1 . Setelah itu biola memainkan lagu dengan disusul instrumen lainnya dalam akord 5. Setelah itu dilanjutkan oleh permainan flute untuk menggiring masuk ke bagian intro dengan irama langgam Jawa danflute atau biola memainkan melodi pengantar lagu. Melodi yang dipakai biasanya adalah 4 birama dari bagian $\mathrm{C}$. Pada pengantar lagu gaya permainan instrumen yang digunakan mengimitasi gamelan Jawa dengan menyerupai laras pelog. Selanjutnya masuk bagian A terdiri dari 7 birama, 4 birama pertama masih menggunakan sistem musikal jawa dengan nada berat Do (1) pada birama 1 dan 2, nada berat $\operatorname{Si}(7)$ pada birama 3 dan 4 . Kemudian pada birama ke 5 sampai ke interlude menggunakan sistem musikal barat dimainkan dengan gaya permainan instrumen keroncong asli yang disebut pola engkel, disusul bagian $\mathrm{B}$ yang terdiri dari 10 birama, dalam bagian B 4 birama awal masuk B masih memakai pola 
engkel keroncong dan bagian $\mathrm{C}$ yang terdiri dari 8 birama bagian koda berupa progresi kord $1-4$ - 5 - 1. Adapun skema strukturnya adalah sebagai berikut ini.

\section{Lagu Keroncong Setia Janjiku}

|| prospel|

$|1 \ldots| 4.5 .|1 \ldots| 4.5 .|1 \ldots| 1 \ldots \mid$

Irama langgam irama keroncong

A. $\quad|1 \ldots| 4 \ldots|7 \ldots| 7 \ldots|2 \ldots| 2 \ldots \mid$ Irama langgam irama keroncong

$|5 \ldots| 5 \ldots|5 \ldots| 5 \ldots \mid$ interlude

B. $\quad|4 \ldots| 4 \ldots|4 \ldots| 4.5 . \mid$

Irama keroncong

$|1 \ldots| 1 \ldots|5 \ldots| 5 \ldots \mid$

Irama langgam

C. $\quad|1 \ldots| 4.5 .|1 \ldots| 4.5 . \mid$

Irama keroncong

$|1 \ldots| 1 \ldots|5 \ldots| 5 \ldots \mid$

Irama langgam

Coda. $|1 \ldots| 4.5 .|1000|$

suwuk

Notasi 4. Struktur serta progresi akord dan seleh pada lagu Kr. Setia Janjiku

\section{SIMPULAN}

Upaya pembaruan dengan cara penggabungan dasar-dasar seni menjadi alternatif untuk seniman kreatif yang hidup dalam dunia industri. Hal itu tidak merubah posisi tradisi musik yang sudah ada, namun justru berdampak pada musik Indonesia yang lebih beragam. Bentuk garap dan masuknya unsur-unsur lain pada lagu keroncong Setia Janjiku menunjukkan gaya penciptaan Ismanto yang berbeda dengan komponis lainnya di era itu. Ismanto telah banyak mencipta lagu jenis keroncong asli maupun jenis langgam Jawa, dari pengalaman itulah yang membuat seorang Ismanto mampu menciptakan dan menggabungkan kedua gaya yang berbeda menjadi satu. Adanya unsur-unsur yang menyimpang dari lagu keroncong asli pada umumnya bukan karena ketidaktahuan, melainkan karena kekayaan pengalaman musikal Ismanto dalam menciptakan lagu. Lagu Setia Janjiku umumnya disebut sebagai lagu keroncong asli, namun tidak sepenuhnya demikian karena merupakan wujud perpaduan antara keroncong asli dan langgam Jawa. Oleh karena itu, Lagu Setia Janjiku dapat disebut sebagai lagu keroncong asli yang nglanggami.

\section{DAFTARACUAN}

Akbar, Neo. 2013. "Perkembangan Musik Keroncong Gaya Surakarta Tahun 19201970.”Universitas Negeri Yogyakarta.

BJ, Budiman. 1979. Mengenal Keroncong Dari Dekat. Jakarta: Perpustakaan Akademi Musik LPKJ.

Damono, Sapardi Joko. 2014. Alih Wahana. edited by Sonya I Sondakh \& Prisca Delima. Ciputat: Editum.

Darini, Ririn. 2012. "Keroncong: Dulu Dan Kini." Mozaik Jurnal Ilmu-Ilmu Sosial Dan Humaniora 6(1):19-20.

Fikri, Mohammad Tsaqibul and Zulkarnain Mistortoify. 2019. "Prospel: Kemunculannya Pada Musik Keroncong." Institut Seni Indonesia Surakarta.

Galtung, Johan. 1970. Diacronic Generalitation, Poces Generalisys \& Causal Analisys. New York: Peloncut.

Ganap, Victor. 2011. Krontjong Toegoe. 1st ed. Yogyakarta: Badan Penerbit Institut Seni Indonesia Yogyakarta.

Gell, Alfred. 1998. Art and Agency: An Anthropological Theory. Oxford: Clarendron Press. 
Harmunah, S. 1987. Musik Keroncong Sejarah, Gaya, Dan Perkembangan. Yogyakarta: Pusat Musik Liturgi.

Kiswanto, Rr. Paramitha Dyah Fitriasari, and Timbul Haryono. 2019. "Transformasi Multipel Dalam Pengembangan Seni Kuda Kepang." Dance and Theatre Review: Jurnal Tari, Teater, Dan Wayang 2(1):1-16.

Nardi, W. S. n.d. 'Keroncong.” Manuskrip Koleksi Ari Mulyono.

Nettl, Bruno. 2012. Teori Dan Metode Dalam Etnomusikologi (Ter. Nathalian H.P.D Putra). Jayapura: Jayapura Center of Music.

Nugroho, Yermia Sapto. 2015. “Analisis Teknik Permainan Gitar Dalam Irama Keroncong Pada Hamkri Surakarta." Universitas Negeri Yogyakarta.

Rachman, Abdul. 2013. 'Bentuk Dan Analisis Musik Keroncong Tanah Airku Karya Kelly Puspito." Harmonia - Journal of Arts Research and Education 13(1).

Ratna Sari, Dani. 2015. "Perkembangan Musik Keroncong Di Surakarta Tahun 19601990." Avatara 3(2).

Sodik, Muh. 2002. "Andjar Any, Proses Kreatif Penciptaan Lagu, Sebuah Biografi." Institut Seni Indonesia Surakarta.

Suadi, Haryadi. 2017. Djiwa Manis Indoeng Disajang. Bandung: Kiblat dan Pustaka Jaya.
Sugiyanto, Danis. 2003. "Sumbangan Komponis Gesang Martohartono Terhadap Musik Indonesia." Universitas Gadjah Mada Yogyakarta.

Wardani, Novelia Kusuma. 2014. "Peran Dan Kreativitas Ebiet Soedaryanto Dalam Perkembangan Musik Keroncong Di Kota Surakarta.” Institut Seni Indonesia Surakarta.

Widyanta, Nugrahanstya Cahya. 2017. "Efektivitas Keroncong Garapan Orkes Keroncong." Jurnal Kajian Seni 03(02):165-80.

\section{Narasumber:}

Danis Sugiyanto, 48 tahun, Akademisi ISI Surakarta, praktisi karawitan, praktisi keroncong, pemain biola. Gentan, Sukoharjo.

Hartono, 67 tahun, Pensiunan karyawan musik RRI Surakarta, pemain Gitar. Semanggi, Pasarkliwon, Surakarta.

Kus Sudiarso, 58 tahun, penyanyi keroncong, pencipta lagu. Laweyan, Surakarta.

\section{Catatan Akhir:}

${ }^{1}$ Era perkembangan musik keroncong ketika dianggap telah mencapai puncak estetika yang ditandai dengan pemberlakuan pakem (konvensi bentuk) dengan karakteristik dan gaya musikal yang bermacam-macam, komposisi bersetting 7 (biola/string instrument, flute/wood wind, bass, cello (selo), cak (banyo), cuk (ukulele), dan gitar), dan banyaknya produksi karya-karya oleh seniman beserta kesenimananya (Ismail Marzuki, Ismanto, Gesang, Mardjo Kahar, Andjar Any, Waljinah, Mini Satria, Budiman B.J., dan lainlain). 